\title{
Analysis of System of Personages and Composition of «The Double, or My Evenings in Malorossia» by A. Pogorelsky
}

\author{
T. P. Vorova \\ Docent, Candidate of Philological Sciences, \\ Department of Foreign Languages for Humanitarian Specialities, \\ Oles Honchar Dnepropetrovsk National University \\ E-mail address: kryptos11@mail.ru
}

Keywords: image-symbol, behavioural models, relationships between man / woman, types of love.

\begin{abstract}
Antony Pogorelsky (1787-1836) (the pseudonym of A. A. Perovsky) was one of the writers active in the early stages of Russian romantic prose, when romanticism, with its new artistic outlook based on rapt attention towards and keen interest in the inner world of feelings and emotions of its literary heroes, replaced the literary movement of sentimentalism with its orientation toward the ideas of the enlightenment. The current article is aimed at the investigation of the first book by A. Pogorelsky «The Double, or My Evenings in Malorossia», the novelty of which lies not only in the fact that the book is directly correlated with the traditions of West European romanticism (which was undoubtedly well-known to the writer), but also in the introduction of a new principle of composition into Russian literature (the cycle of several stories united through dialogic framing), which was the first experiment of this kind in the Russian literary environment and would soon become one of the favourite techniques of other Russian romanticists.
\end{abstract}

\section{INTRODUCTION.}

Being the illegitimate son of one of the most famous and influential Russian families in the times of reign of Catherine II - Count A. K. Razumovsky, A. A. Perovsky became a well-educated man with thorough his knowledge of literature: he graduated from Moscow University, took the highest academic degree of Doctor of Philosophy, spoke German and French perfectly and displayed an outstanding talent for literature. His influential father obtained for him the title of the nobility, as a result of which A. A. Perovsky had an opportunity to become a high official at one of the departments in the Senate. He was familiar with many famous writers in Russian literature of the period (A. S. Pushkin, V. A. Zhukovsky, P. A. Vyazemsky et al.) and took a noticeable place in literature of the $1820 \mathrm{~s}-1830 \mathrm{~s}$, playing a large role in the formation of romanticism.

The talent of A. Pogorelsky as a writer is shown in the combination of ironical and jocular mystification (that naturally enters the author's literary method and represents its original distinctive characteristic) and common sense (the independent and penetrating look at some habits and customs which the author can professionally trace): taken together, it manifests the individuality of the writer uniting the rationalism of the past XVIII-th century and the romanticism of the XIX-th century in a unique creative personality. These features are brightly demonstrated in the author's first book «The Double, or My Evenings in Malorossia» (1828) [6, p. 23-160], which was a literary first in several respects (the first Russian fantastical fairy tale appears in the structure of the book, for the first time all the stories are put into form of a cycle with a single narrator, it is the first romantic book in Russian literature according to its contents). The book consists of four short stories, which are united with help of dialogic framing, vividly embodying the duality of the author and manifesting his psychological split consciousness, where one may observe the interweaving of the bearer of philosophy of positivism from the past epoch and the representative of the new and fashionable modern romanticism with its passion for magnetic power, presentiments, predictions and ghosts. This is borne out by the vast dialogues between the author and his double, in which the attention of the interlocutors is always located between two poles - keen interst in the abovementioned romantic themes and attempts at their rational materialistic explanation. In these discussions the Double does not abandon his role as a positivist and argues at length about the 
features of human intellect rooted in materialistic philosophy; however, the mere fact of the unusual appearance in the narrative of the strange Double (completely fantastical by his nature) contradicts all possible rational explanations. This uncommon tendency to combine rationalism with fantasy, creating an absolutely incredible form of rational fantasy, fundamentally distinguishes the cycle by A. Pogorelsky from western romantic models; later the same tendency will be used in Russian romantic prose, first of all, in the outstanding literary monuments «Evenings at a Hamlet near Dykanka» by N. V. Gogol [2] and «Russian Nights» by V. F. Odoyevsky [4]. But, in contrast to N. V. Gogol and V. F. Odoyevsky, the two debators created by the writer A. Pogorelsky practically represent the same person with an introspective consciousness, inside which the rational/ enlightening and romantic beginnings compete against each other (it is natural that the appearance of the Double is the exact portrait of the author, i. e. it is, in fact, a self-portrait, and again this detail reminds one of the writer's love for mystification). These creative individual peculiarities help one to understand the different short stories set into the author's cycle.

\section{DISCUSSION.}

The formal framing of the cycle «My Evenings in Malorossia» performs the double function: 1) as the skeleton for the installed stories / fairy tales in which the writer introduces himself under the guise of his own Double, who represents the mirror image of the author's alter ego; not without reason, all their conversations display the polarity of the author's and his guest's points of view (the down-to-earth or rational / materialistic variant regarding various problems is announced with the help of the author's Double, the ideal way of looking at the same subject is sounded out with help of the writer); 2) the second function directly flows from the first one, representing the framing of the cycle as another all-purpose and all-embracing piece of writing with the insertion of four strange, unfamiliar stories, the expression of which is immersed and fused into the main texture; from the point of vew of their contents, they are not connected with each other in any way, but they embody the author's idea about four main models of human behavior and include four generalized plot lines (which are perceived as strange and distinct expressions), which serve as the certain background on which the models of different moral codes and relationships are displayed.

A Double is required by the author in order to duplicate and project himself into literary space as a human being (this writer's method should be perceived as the author's special sign, otherwise the disputes with the Double might be simplistically apprehended as the imprint of the intricate philosophizing of the writer wasting time for his own pleasure). To further reinforce this functional border of the framing narration, the special conversation between the Double and the writer is introduced in the chapter "The Fourth Evening» [6, p. 87-101]: it is presented in the deliberately abstract form of scientific research without any connection with real people or events (something like a modern informational bulletin about the results of a survey of large groups of people or events). The scientific form of this dialogue-research is highlighted through special, dry, condensed, laconic language (typical for scientific publications), as well as the introduction of the classification of the object of discussion - the human intellect in its various manifestations - in order to illustrate the difficulties of understanding the theme with the help of visual methods (three diagrams and a table) along with the corresponding instructions about the practical use of this scientific instrument in conditions of individual experience.

A thoughtful reading of the dialogue reveals the accentuation of the facts of the mind's defects advisedly underlined by the writer, and it results in the manifestation of the corresponding weaknesses in human behaviour, which, in their turn, are subdivided by the writer into another classification with «the highest and lowest categories» [6, p. 94] and their accompanied analysis. The conclusion claims that the defects and weaknesses preponderate in the vast majority of members of all social classes: something that is frequently taken for intellect and virtue proves on closer examination to be composed of absolutely different qualities, and they have nothing in common with a positive, healthy mind and behaviour. Here it is useful to recall «Tale of Pope and Balda» by A. S. Pushkin [7, p. 600-604]: Pope only seems to be clever but in fact he shows a complete absence of mind, he must be a sage, whereas the results of his actions / behavior reveal 
the attempt to substitute different qualities (slyness or fraud, for example) for intellect; at the same time Balda (his name in the Russian language indicates lack of intellect) demonstrates the bright examples of a brilliant mind in its different aspects: perspicacity, common sense, docility, prescience, sharpness, gumption, etc. (the given terminology is taken from the table of the positive characteristics of mind in the analysed chapter of the cycle «My Evenings»). From the material mentioned above, it is obvious that there are distinct parallels between the two literary works: something that is narrated in artistic form in the fairy tale by A. S. Pushkin possesses the form of scientific analysis in the cycle by A. Pogorelsky.

Basically, the cycle «My Evenings» includes two lines forming the general structure of the literary work: 1) unusual, mystically coloured events from life and natural explanations for them; 2) stories about love and relationships between man/woman («Isidor and Aniuta», «Ruinous Consequences of Unruly Imagination», «Seller of Poppy Cakes from Lefortovo», «The Journey by Coach»), in which complicated, fanciful, fabulous/fantastical narrative tracery is imposed on the fabric of plain routine reality and cannot be explained from a rational point of view.

The first short story «Isidor and Aniuta» conceals the typical plot beneath the external form of the romantic story about love. The argument of the story is as follows: on the eve of the entry of French troops into Moscow a Russian nobleman Isidor returns home in order to see his old mother, who is near death, and his beloved bride - an orphan girl brought up in this family. The heart of Isidor is torn between his sense of honour as a Russian officer (with the duty of defending his motherland against the enemy's invasion) and the duty to protect two weak women against the same advancing enemy. The decision of the hesitating hero bends towards staying at home, however his mother orders the youth to return to his military unit. There are two narrative lines in this short story: Isidor/old mother, Isidor/Aniuta. The united characteristics of tsarina I and tsarina II from «Tale of the Dead Princess» by A. S. Pushkin [7, p. 634-646] become apparent in the portrait of the hero's old mother: this woman sheltered and brought up the orphan Aniuta in her family (the function of tsarina II), but treated her tenderly as if she were her own mother (the function of tsarina I). The old mother respects the warrior / defender in her son, however caste honour is above all for her (even the problem of her own safety is not taken into account), as a result of which she is categorical in her will: the mother's benediction is destined only for her son-warrior, but not for the pusillanimous youth, looking for an excuse to stay longer in the family and stay out the war time next to his lares and penates, which would be a transgression of the law of honour. In the old woman's opinion the warrior's bravery and military valour must be shown on the battlefield in the defence of the motherland. On one hand, this is the manifestation of great patriotism of the mother, who gives her blessing to her son to perform heroic deeds and, most likely, to die; on the other hand, this is the obvious manifestation of the aristocratic code of behaviour (the tsarina II was exactly the same: she always conducted herself comme il faut, i. e. in conformity with the code of honour of the aristocratic caste). The relationship of the lovers Isidor and Aniuta is subordinated to the same call of duty and honour; the heroine (answering Isidor's question about her protection) responds decisively, pointing at a dagger: «I will remember my duty; you will meet me deserving of you, or you will not meet me at all!» [6, p. 44]. The image of Aniuta is traced weakly from point of view of human qualities; the only feature highlighted in this personage is the heroine's fidelity to her family, stepmother and groom (Aniuta kept the word she had given to Isidor and preferred death to life in disgrace; even from the other world her soul tried to show her fidelity to Isidor in order to convince him of her true love) and her adherence to the life principles that formed an integral part of her aristocratic upbringing. In these aspects the heroine can be directly compared with Pushkin's dead princess, whose characteristic feature is endless fidelity.

It should be noted that Isidor unites the functions of Pushkin's prince Yelisey and the seven herculeses. In the hypostasis of Yelisey Isidor tends to defend his lover and mother against real death; in the hypostasis of the seven herculeses he is ready to sacrifice his life to fatherland. That is why his heart and soul are torn between two aspects of duty, of which the hero inclines to choosing the variant of duty of Yelisey; however, his mother has the casting vote in the discussion with her son and bends Isidor to perform the function of the seven herculeses. Thus, in this story the first 
behavioural model is presented in the form of a specific combination of features typical for an aristocratic milieu.

In the next story from the cycle - «Ruinous Consequences of Unruly Imagination» - a completely different plot scheme is used. The argument of the story is as follows: Earl Alcest, aged 20, goes to Germany for his studies, where he falls in love with Adeline, a girl with stunning features, he is married to her and commits suicide because during the wedding night the horrorstricken young hero discovers that the delightful bride is, in fact, a skillfully contrived mechanical doll. It is necessary to focus attention on the fact that, besides Alcest, all other men who have seen Adeline even once, unavoidably fall in love with her; however, only Alcest passionately, powerfully, hotly and romatically loves the girl, to whom he has never managed to speak, meet at a rendez-vous in person or even take by the hand; the only thing that is accessible for the hero is to behold the beauty for long hours in the window frame in the building across his own house; i. e. in reality the hero falls in love with some refined portrait (the image of the doll in the window frame is the transparent equivoque of the average portrait of abstract beauty combining the typical features of other beauties: locks, eyes, lips, face, figure, etc.). A portrait cannot socialize, which is why Adeline is also devoid of the ability to speak (although she has the ability to move). A portrait does not have any feelings or emotions, it does not own the capability to love - in the same way the heroine is lacking in heart and soul. And even so, Alcest madly loves the portrait / mechanical doll and does not have the strength to resist his corrosive passion, depriving the hero of his ability to think rationally, draw the logical conclusions regarding the real situation and control his own behaviour.

The plot line Alcest / Adeline directly correlates with the plot line Dadon / Shamahanskaya tsarina from «Tale of the Golden Cockerel» by A. S. Pushkin [7, p. 647-653] because Dadon also ardently falls in love with an eastern beauty at first sight, losing control of the situation and completely falling under the power of chance and fate; as far as is known, Dadon dies just after returning home (several weeks have elapsed from the time of the hero's meeting with the tsarina till his death, just as only several weeks have passed from the time of the meeting of Alcest with Adeline till his wedding with the doll). The second plot line connecting the story with Pushkin's fairy tale presents the personification of Pushkin's astrologer/wizard in the image of the cunning and resourceful inventors of the devilish mechanical doll - the Spaniards Venturino and Androni. Devilish things slip even into the description of appearance of these personages (the black wig/fiery red eyes of Androni and the red cloak / the black cocked hat of Venturino; the black / red color spectrum is associated with the world of hell and evil wizards). In Pushkin's fairy tale the creation of the magician - the cockerel - finally kills Dadon; just as the creation of Venturino and Androni - the doll Adeline - destroys Alcest; the real reason for all the events is rooted in the old quarrel between Alcest's father and Androni, the result of which was the oath of the ventriloquist Androni to avenge himself upon the earl and destroy the earl's family; Androni realizes his plan skillfully and ingeniously. The swift deaths of Alcest/his father because of the persecution by the evil genius correlate with the swift deaths of the tsar's sons and Dadon as the consequence of the quarrel with the wizard from Pushkin's fairy tale. Thus, this story represents the second behavioural model in the form of combination of characteristic features of all personages and the use of specific plot lines (love at first sight, passion for the object of love, death of the hero).

The same theme of love for a doll is traced in two fairy tales from the cycle «Motley Fairy Tales with Witticisms» by V. F. Odoyevsky [5]. The difference is in the interpretation of the point: A. Pogorelsky represents love for a doll in tragic tones whereas V. F. Odoyevsky tends to use a drier, pedantic/didactic tone, although the heroine-doll of V. F. Odoyevsky and her lover suffer torments because of mutual misunderstanding and absence of common interests.

The third story «Seller of Poppy Cakes from Lefortovo» is totally orientated towards the fairy tale genre, the specialist in study of literature M. A. Turian [8] defined it as the first Russian fantastical fairy tale. The argument of the story is as follows: a modest postman Onufrich has a family: wife Marfa Ivanovna and beautiful daughter Masha, aged 17. Masha is a favourite of her old childless aunt (seller of poppy cakes) who, in fact, is a witch. Keeping this a secret from her 
husband, Marfa Ivanovna asks the aunt-witch for help in order to marry off Masha to a rich man with use of magical art. The day before her death the old witch performs the corresponding rite with Masha; soon the girl marries. The thrilling and gripping plot of the fairy tale attracts the reader with the richness of its symbolism, dissemination of humorous situations and frightening meetings with weird representatives of the supernatural.

Let us first analyse the main plot lines connected with the events in the life of the main heroine - a witch and sorceress, her significance is underlined with the fact that this personage is incorporated in the title of the fairy tale. The name of this enchantress is not mentioned in the narration that is why her image should be considered as a generalized portrait of the representatives of this profession. The woman is very old (the image-symbol of the extreme antiquity of her occupation), therefore, she has managed to hone her skills within a long lifetime. Many people approach her to ask for help (according to law of the genre, the witch receives the visitors late at night because performance of the rites requires the dark period of the daily cycle), she renders assistance to everybody even though she has her own self-interest and extracts her profit: the payments are taken individually depending on her compliance with the request of the visitor and his financial state. The witch-sorceress is fair and does not do deliberate evil to other people, however if somebody dares insult her, she always retaliates against her offenders, that is why the neighbours treat her with all possible respect. It is supposed that the old woman is rich, but nobody can measure her wealth as she leads a modest lifestyle in a secluded house in Lefortovo near Moscow (this is reflected even in the title of the fairy tale - «Seller of Poppy Cakes from Lefortovo»), and this name of the place serves as an extra author's mark linked with the professional activity of the heroine because Lefort - the fellow-fighter of tsar Peter I - was famous for his deepest erudition and practices in the specific field of competence and knowledge of mysteries.

The indication of the heroine's occupation (seller of poppy cakes) underlines the outer side of the her social profession that is open to everybody, but at the same time it is another author's mark that highlights in a symbolic way either the specific character of the witch's activity or the magic power used in this profession. In the XIX-th century the words «seller of poppy cakes» indicated the woman-sellers who sold flat round cakes with mashed poppies, but the heroine added honey into the cakes to make them sweeter. It is known that in the esoteric context flat cakes embody the circularity of the full moon (if they are with a cross on the right side it means the four phases of the moon), whereas poppy is one of the most widespread vegetable symbols of the Great Mother-Goddess in her aspect of nocturnal and lunar deity, which highlights such of her qualities as prosperity, fertility and proliferation; in this context poppy represents the emblem of numerous personifications of the Great Mother-Goddess (Ceres, Venus, Persephone, etc.). The Great MotherGoddess is Nature itself: it is universal Mother, sovereign of all elements, primordial child of time, Tsarina of all spiritual things, death and immortality, progenitress of all existent gods and goddesses, she governs the Light of the Heavens with the simple movement of her finger, she rules the benevolent sea winds and the grievous silence of the underground world. In the attempt to propitiate her in many ways she is worshipped in her different aspects and manifestations known under a countless number of names. Thus, the poppy cake is an object which is universal by its designation (the seller of poppy cakes not only sells the cakes but also gives them away free to the soldiers of the Lefortovo garrison and to passers-by if she has done some extra baking; allegorically it symbolizes the Great Mother-Goddess as the terrestrial wet-nurse) and a deeply symbolic object that is directly corresponded with the Great Mother-Goddess in her aspect of lunar deity. And finally, the honey added into the cake by the witch is always thought to be divine food, since ancient times it was used as the gift for gods; in ritual ceremonies honey was identified with the waxing moon and in this way - with the augmentation of material benefits and abundance of money. This element can explain the reason why the old witch was so rich: she was not only a simple enchantress and priestess of the Great Mother-Goddess in her aspect of lunar goddess (it is shown textually that the heroine performed all rites only late at night), but, multiplying her own wealth, she also derived material and financial benefit from her state (the old heroine is sorry about 
having to leave this world very soon because she wishes «to admire her gold coins for a longer time» [6, p. 110], as she loves money most of all).

The other professional and occult image-symbol of the witch is her favourite black cat. The cat's ability to change the shape of its pupil transformed this animal into the live personification of the phases of the moon and the enchanting luxury of night, i. e. the cat introduces another symbol of the lunar goddess as her chthonic power (having a diurnal and nocturnal lifestyle, the cat represents the guide to the light/dark worlds and the herald of good / bad news). In the analysed fairy tale the black cat does not harm anybody, it is depicted as the active functional helper of the witch during her rites, its meowing notifies the exact nocturnal time, and the cat itself executes the role of the witch's messenger in the dark world, which has different levels to which the cat delivers the orders or requests of its owner. The cat also represents the image-symbol of full freedom and actions done furtively; it is no wonder that the witch adores her black helper, and afterwards she even comes to the conclusion of marrying her cat (who has the ability to take the shape of a human being) to her only granddaughter. The image-symbols of flat cake, poppy, honey and black cat makes, in total, the number «four», which symbolically points to the element of earth - another chthonic power linked with the strength of the Great Mother-Goddess and, consequently, with the principal magical power of the witch.

The heroine leads the kind of lifestyle that corresponds to her wishes and tastes, does not offend other people unless the stupidity of neighbours induces her to self defence. One example of this kind cooled off the hotheads at Lefortovo - it was an episode of punishment of a neighbour's family because of an offence that hurt the sorceress deeply, and it served as an instructive and sobering example for those who assumed the illegal right to point out the oddity of the witch's lifestyle. The punishment is thrice-repeated in the narration - twice with the members of the offender's family, once - with the cow-wet nurse (it reflects the popular belief that, if unexpectedly and without any reason a domestic animal begins to feel pain and dies, it is an obvious sign that a witch or a wizard was offended by the owners of the domestic animal). Also, the sacral principle of triplicity and the number «three» was used in the witch's magic rite during the ceremony with Masha: these details focus the reader's attention on the magical side of the witch's activity even more than earlier. Unfortunately, the witch's nephew Onufrich, who is not aware of the specific character of the old lady's lifestyle, does not make any conclusions for himself from the accident. Moreover, having too high an opinion of himself as the bearer of the Christian virtues to which, in his eyes, the aunt-witch should adhere, he comes to her place determined to persuade her to accept his values, which results in immeasurable anger and offence on the part of the old woman/enchantress with higher social/spiritual status, and then the full rupture of her relationship with her relative follows. So, the heroine-sorceress in the fairy tale is neither good nor bad - she is self-willed, lives according to her own canons and rules and does not heed the values of the world of ignoramus, i. e. she is wise. Like the Great Mother-Goddess, her priestess (inside her own personality) duplicates the dualities of the creator and the destroyer: she almost comes to curse her stupid nephew who offends her, however, she displays mercy to her only granddaughter Masha.

Being physically beautiful, Masha does not have any suitors because she is without dowry. The prospect of remaining unmarried saddens the girl and seriously perplexes her mother, who quarrels with her silly husband because of his breaking off relations with the influential and well-off kinswoman. Without telling her husband, Marfa Ivanovna visits her old aunt begging her to arrange her granddaughter's marital future. The old woman invites Masha to come to her place at midnight. Owing to the special importance of the further events, Masha's nocturnal visit to the witch's house is worthy of special attention. The magical action performed represents a certain rite but the author restricts it to its starting and final episodes: the old lady puts a table in the middle of the room, lights coloured candles, walks with Masha around the table three times (naturally, the cat participates in all operations); and then the girl loses consciousness because of her fear (the image-symbol of minideath); coming to her senses, she finds out that she should expect positive changes in her personal life and rapid enrichment. This episode sets the obvious scene of the initiatory mystery of a new adherent who is attached to the secret source of strength and power of the Great Mother - goddess 
of the nocturnal luminary. A number of important detail-symbols support this interpretation: time of action (midnight); four elements of power are used: the wind is wildly howling outside (the element of air), the candles are lit (the element of fire), the old woman personifies the goddess of Earth (the element of earth), in the end Masha is splashed with water (the element of water), the presence of the black cat is equated with the presence of the particular magical power of night, the fainting of the girl embodies passing over the threshold of death.

Thus, Masha passes through the initiation procedure and is connected to the power of a certain magical source that is rooted in the cult of worshipping the Great Mother-Goddess. And the most important thing is the fact that the old woman gives a particular enigmatic key to Masha, which must be cherished as the apple of her eye because it must help to Masha to master the occupation of witchcraft and in that way to increase her money and wealth. This is a very significant detail as it is well-known that the Great Mother is Tsarina of Heavens, Mother of Gods, opening the path, keeper of keys, prolificacy and gate of birth, death and resurrection. It is obvious that the girl is initiated to pass the path of spiritual evolution through the dedicatory ceremony of initiation into the Great Mother, the proof of which is the passing into Masha's possession of the key (only the next day the old woman dies, as according to popular belief a witch cannot die without leaving an inheritrix in place of herself - precisely this thing happens in the analysed fairy tale; however, even after her death the sorceress appears in front of Masha in order to continue to instruct the girl). In order to advance along the spiritual path, the sorceress demands the strict fulfilment of two conditions from Masha: to keep piously the presented key and to marry the person sent by the witch. But Masha manifests self-will, breaking the grandmother's plans: meeting the groom (the titular councellor Aristarh Faleleich Murlykin), she recognizes the granny's cat in him and absolutely refuses to marry the cat-official, who is depressed by her behavior because he does not expect such treachery from Masha. The parents of the girl (especially, her mercenary-minded mother) are also in perplexity - the official is well-off and represents a parti for poor Masha. But the girl is sure that money cannot make her happy if there is not the happiness of sincere love.

The author supplies the key for better understanding of this manner of behaviour on the part of the heroine with the help of the casually mentioned note that «the human heart $\langle\ldots\rangle$ is such a labyrinth in which the most skilled observer can easily lose the thread of Ariadne» [6, p. 93]. Therefore, the reasons for the unexpected behaviour of the girl, who, not long ago, was desperate to marry and get riches, must be searched for in herself. But what exactly influenced the girl's decision - virtue, vice, weakness or anything else that she was not aware of herself? In this case the author's mention of the thread of Ariadne supplies the precious code to the cypher which can help to decode the secret. So, the Great Mother in her hypostasis of lunar goddess is the measure of time, and she is $a$ weaver of destiny because all GreatMothers are the spinners and weavers, spinning a web from the thread of destiny: it symbolizes her power either to circumvent/tie together or release. It turns out that within the short period of time passed from the night of Masha's initiation till the day of arranging her match with Mr. Murlykin the girl, left alone for some time, suddenly falls in love with a youth Ulian, a man who works in a merchants' shop; Ulian's behaviour proves that the amorous attraction turns out to be mutual. However, the modesty of his character and of his social status prevent the hero from displaying his love to Masha. And she is dreaming whole days and nights of the youth who charmed her heart and soul; with the ardour of youth she imagines how she could manage her happiness with her beloved. The girl is not deterred by the fact that the boy is poor; she is encouraged and inspired by her love, and she completely plunges into the sweet delight of her amorous feeling. Against this background, Mr. Murlykin's matchmaking is interpreted by Masha as blasphemy and sacrilege, which insults her elevated love; she is filled with abhorrence when she thinks of the cat-official; Masha accepts as the only variant of her marriage - the love-match with Ulian. In order to get rid of the obligations towards her witch-grandmother once and for all, the girl throws the precious key into a deep well. Because of a queer concourse of circumstances it is Ulian who requests her marriage the next morning, and his father turns out to be a well-off man. How could this happen? It is necessary to remember that the girl passed through the initiation rite which reveals the inner potentiality of the girl and reinforces her energy. Without knowing it, Masha in her 
sublime spiritual state wove/plaited the new light thread of destiny for herself, in which there was a place for her love and the object of her love, at the same time there was not a place for the grandmother's dark bewitching profession. If at the beginning Masha acts by order of her mother, who is struck with demon of greed and, correspondingly, the girl dreams only of riches, after the initiation the dictate of heart and soul comes to the foreground because the heroine realizes that love cannot be bought. She starts to trace attentively all possible demonstrations of her trembling heart (it is she who examines herself carefully - covering her heart with her hand - in order better to feel if her heart pounds or not when she first sees Ulian passing by). By throwing the key into the well (which is the image-symbol of the chthonic power of the Great Mother-Goddess), Masha refuses to follow the dark night's (or grandmother's) path and leaves for herself the light day's (or her personal) path of happiness of heart and soul. Thus, the girl makes her choice of one of the directions (dark or light) of spiritual evolution that is inevitable for all initiated people; it is her right, and she uses it in full. Masha becomes the sorceress of the light path and leaves her departed grandmother without any follower on the Earth (as a result, the black cat completely disappears and never shows up in the life of heroine).

At the very beginning of his novella «The Double» the author introduces the peculiar motto of the cycle: «Enjoy what is given by God; do not feel sad about what is not given and absent». In the analysed fairy tale this motto gives the possibility to see the faintly traced light associative connection with religious and mystical content through the name of the protagonist Masha, which bears (tentatively indicated) the lofty spiritual features of the Christian Virgin Mary (according to the esoteric doctrine The Blessed Virgin Mary is the hypostasis of the same Great Mother but only in her chaste and virgin aspects) who forges physical, emotional and spiritual beauty in her heart through the all-triumphant power of love. That is why the symbolism of the childless old womanwitch who was unable to start a family (the symbol of rejection of the inclinations of the heart and of any relationships with men in favour of the path of intellect in order to gain purely material results) is opposed to the love and harmony of the family happiness of Masha (the symbol of the fundamental nature of the all-conquering path of heart).

In the fairy tale the sacral doctrine of the white race is presented in artistic form - this is the doctrine of spiritual development according to the model of passing along the path of the heart or the safe and right way of evolution (embodied in the fairy tale in the symbolic love story of Masha) and the model of developing on the path of the mind or the dangerous left way (presented with help of the image-symbol of the witch-sorceress and her activity). The author avoids the introduction of his personal evaluative opinions about each of the paths in any way, he only displays the smooth progression and, correspondingly, preferences for one or the other model of the doctrine, among the different generations of the same family. In the fairy tale, the old witch and Masha's mother, for example, are quite rational in their passion for money and, therefore, they are close to each other in their judgement of life (from point of view of availability/lack of material prosperity and wealth). Masha totally rejects this attitude to life because only love is significant for her, and money takes secondary importance in her priorities. But the above preferences are not firmly fixed, and it is quite possible that the next generation of the family might change the polarity of the orientation of its general priorities, and the indicator can again be jolted to the left, to the side of the rational approach in life in order to be closer to material gains. The choice is always individual and is governed by numerous causes.

As a whole, the fairy tale is built on the principles which were brightly depicted in «Tale of Tsar Saltan» by A. S. Pushkin [7, p. 606-629[, as in the analysed piece of writing the women are the key personages in the narration (this is reflected in the title of the fairy tale) and have the last word in the family affairs (the wife, the old aunt and the daughter give a hostile reception to all decisions of Onufrich, which do not have any further realization without the women's approval); the model «weak man/strong-willed woman» corresponds to the family structure analysed in detail by A. S. Pushkin in «Tale of Tsar Saltan». In the present story there is the following division of functions coinciding with those used in Pushkin's fairy tale: the old seller of poppy cakes (the leader of the family) must surely be Babariha; Saltan is personified in Onufrich, whose will is subordinate to the 
women (the wife and aunt-sorceress); Masha embodies the self-willed princess Lebed, who chooses her future husband herself trusting only her heart and ignoring anybody's advice; Ulian must certainly be the prince Guidon catching the attention of princess Lebed. Therefore, in general outline the plot matrix of the story coincides with the plot model presented in Pushkin's fairy tale of Saltan.

The story «The Journey by Coach» describes the meeting of two travellers on a coach on their way from Moscow to Saint Petersburg, one of the travellers - the colonel Fan-der-K. - tells the story of his childhood and youth, when he was brought up by a monkey Tutu that loved and protected him against all adversities, and tried to keep in touch with the boy even after his return home. After becoming an adult, the hero tried to avoid Tutu's obtrusive surveillance and care and accidentally killed her; depression and regret for this deed tormented the colonel as he believed that the moral perfections of this kind animal aggravated a terrible fault which lay heavy on his conscience for a long time. The key for understanding this unbelievable story is introduced in the author's dialogue with his Double in the final lines of his cycle «My Evenings», when both interlocutors were able to reach a rare agreement in their comments on the hero's behavior. It is stated that the colonel is conscience-stricken as his sufferings resulted from his base ingratitude to Tutu; ingratitude is a crime, which is why cruel treatment of the colonel's benefactress is thought to be a villainous vice.

The Double-narrator and the story-teller deepen the same idea, presenting the idea that the opposite scenario also exists when some people demand gratitude but, in fact do not have any rights to it; their impudence can be so boundless that they call themselves benefactors only because they were capable of causing harm to somebody but did not realize their evil potential. The generalized summary claims that one must always appreciate good deeds. As in the "Tale of the Fisherman and the Fish» by A. S. Pushkin [7, p. 629-634], the moral principle used in this short story proclaims that one must manifest altruism and not demand recompense for one's good deeds, and, conversely, thank one's benefactor for any demonstrations of altruism. In a way, the same plot can be traced in the literary work «New Zhako» by V. F. Odoyevsky [5]. Although A. Pogorelsky describes faithful love of a monkey for a man, and V. F. Odoyevsky depicts a family of spiders, the coincidences of plotlines and themes precisely indicate the common points of contact in two works.

\section{Conclusion.}

Taking into consideration all the abovementioned points, it is necessary to state that the cycle «The Double, or My Evenings in Malorossia» by A. Pogorelsky represents a single whole, a literary work grounded on united basic ideas reflecting the strange symbiosis of the rationalism of the XVIII-th century and romanticism of the XIX-th century; the framing, incorporated in the form of pseudoscientific research, cements into a single whole four typical plotlines and four typical behavioural models of the heroes, which can also be found in fairy tales by A. S. Pushkin.

Taken together, the four short stories from the cycle represent the writer's differentiation of four types of love, in which he highlights the relationships between man/woman as certain permanent behavioural models: 1) love-devotion/love-fidelity even after death is presented in «Isidor and Aniuta» (it may be compared with the model of the relationship between tsarevna/prince Elisey in «Tale of the Dead Princess»»» by A. S. Pushkin); 2) love-passion/lovemadness, that turns a man into a slave of love-infatuation, is introduced in «Ruinous Consequences of Unruly Imagination» (this may be compared with the model of the relationship between Dadon/Shamahanskaya tsarina from Pushkin's «Tale of the Golden Cockerel»); 3) profound and sincere love, true love, love-happiness, love-award is in «Seller of Poppy Cakes from Lefortovo» (the same conception of love is shown in the couples tsar Saltan/young tsarina and prince Guidon / tsarevna Lebed from Pushkin's «Tale of Saltan»); 4) love-instinct, love-gratitude, love-duty, lovehonour and, partly, love-benefit is represented in «The Journey by Coach» (this may be correlated with the model of relationship between old man/old woman from «Tale of the Fisherman» by A. S. Pushkin). 


\section{References:}

[1] Cooper G., Encyclopaedia of Symbols, Series «Symbols», Book IV, Moscow, Association of Spiritual Union «The Golden Age», 1995.

[2] Gogol N. V., Evenings at a Hamlet near Dykanka, Collected works in six books, Book 1, Moscow, Khudozh. Literatura, 1959.

[3] 3. Mann Yu., Indisputability of Fantasy: On the Creative Biography of the Writer A. Pogorelsky (1787 - 1836), J. Children's Literature. 8 (1972) 46-49.

[4] Odoyevsky V. F., Russian Nights, Collected works in two books, Book 1, Moscow, Khudozh. Literatura, 1981.

[5] Odoyevsky V. F., Motley Fairy Tales with Witticisms, Facsimile reproduction of the edition of 1833, Moscow, Knyga, 1991.

[6] Pogorelsky A. The Double or My Evenings in Malorossia, The Novice in the Convent, Moscow, Khudozh. Literatura, 1960.

[7] Pushkin A. S., Poems and Rhymes, Fairy Tales, Puslan and Liudmila: poem, Collected works in three books, Book 1, Moscow, Khudozh. Literatura, 1985.

[8] Turian M. A., «Igosha» by V. F. Odoyevsky, J. Russian literature. 1 (1997) 132-136. 